\title{
Efek Perendaman Serat Sabut Kelapa dalam Larutan Alkali Terhadap Daya Serap Serat Sabut Kelapa pada Matriks Poliester
}

\author{
Muhammad Arsyad ${ }^{1, a}$ \\ ${ }^{1}$ Jurusan, Teknik Mesin, Politeknik Negeri Ujung Pandang, Tamalanrea Km. 10, Makassar 90245 \\ a arsyadhabe@poliupg.ac.id
}

\begin{abstract}
The aim of this study is to determine the effects of soaking the coconut fiber in alkaline fluid on absorption capability of the coconut fiber on polyester matrix. The coconut fiber is soaked in natrium hidroksida $(\mathrm{NaOH})$ fluid with concentration of $20 \%$ for duration range of $1,3,5,7,9$ and 11 hours, then dried in room temperature then matrix polyester is given on several parts of the coconut fiber. After dried, wet ability angle is measured using digital microscope to investigate the absorption capability of the coconut fiber on polyester matrix. Every single variable will be examined for three times. Obtained data will be analyzed statistically using discriminative method and will be demonstrated in table form. Based on experiment, soaking of coconut fiber in $20 \%$ natrium hidroksida ( $\mathrm{NaOH}$ ) fluid affects on absorption capability of the coconut fiber on polyester matrix. After soaked, wet ability angle is decreased compared to without soaked. The smallest wet ability angle of $15,327^{\circ}$ is obtained for 5 hours soak duration.
\end{abstract}

Keywords: Natural Fiber, Soaking, alkali, wet ability

Abstrak-Tujuan penelitian ini yaitu untuk menentukan efek lama perendaman serat sabut kelapa dalam larutan alkali terhadap daya serap serat sabut kelapa terhadap matriks poliester. Serat sabut kelapa direndam dalam larutan natrium hidroksida $(\mathrm{NaOH})$ dengan konsentrasi $20 \%$ selama 1, 3, 5, 7, 9, dan 11 jam, kemudian dikeringkan dalam suhu kamar. Setelah itu, pada beberapa bagian serat sabut kelapa diberi matriks poliester. Setelah kering, dilakukan pengukuran sudut wetabiliti dengan menggunakan mikroskop digital untuk mengetahui daya serap serat sabut kelapa terhadap matriks poliester. Setiap variabel akan diuji sebanyak 3 (tiga) kali. Data-data yang diperoleh akan dianalisa secara statistik dengan menerapkan metode deskriftif, dimana semua data-data yang diperoleh akan disajikan dalam bentuk tabel. Berdasarkan pengujian yang dilakukan, perendaman serat sabut kelapa dalam larutan $\mathrm{NaOH}$ 20\% memberikan efek terhadap daya serap serat sabut kelapa terhadap matriks poliester. Setelah perendaman, sudut wetabiliti menurun dibandindingkan dengan sebelum sebelum perendaman, sudut wetabiliti terkecil diperoleh pada perendaman 5 jam yaitu $15,327^{\circ}$.

Kata Kunci :Sserat alam, perendaman, alkali, wetabiliti.

\section{Pendahuluan}

Dewasa ini, teknologi material sangat berkembang termasuk dengan perkembangan material komposit berpenguat serat alam. Salah satu kelebihan komposit berpenguat serat alam yaitu ringa. Hal ini menyebabkan komposit berpenguat serat alam akan menjadi pengganti komposit serat gelas, atau logam. Pada perkembangan tersebut, para ilmuwan sangat memperhatikan prinsip keberlajutan, efisiensi lingkungan secara global, kimia hijau sehingga harus saling terintegrasi antara bahan, pengembangan proses, dan produk.

Serat alam memiliki beberapa kelebihan seperti jumlahnya yang banyak, rendah biaya produksinya. Namun demikian, serat alam juga memeliki beberapa kelemahan seperti kondisi seratnya tidak seragam, memiliki daya serap air yang tinggi, suli berikatan dengan matriks. Hemp, flex, sisal, rami, jute, dan sabut kelapa merupak jenis serat alam yang banyak diteliti dwasa ini. Salah satu hasil penelitian menyimpulkan bahwa komposit yang diperkuat dengan serat alam memiliki kekuatan $40 \%$ lebih kuat dan lebih ringan dibandingkan dengan komposit yang diperkuat serat gelas. Bila kendaraan menggunakan komposit serat alam sehingga bobotnya bisa berkurang berarti akan meningkatkan efisiensi pemakaian bahan bakar [1].

Dewasa ini, pemamfaatan sabut kelapa hanya untuk bahan bakar pada saat memasak, atau membakar ikan. Selain itu, pada skala industri mikro sabut kelapa bisa digunakan untuk membuat keset kaki, tali, atau sapu. Padahal, sabut kelapa bisa diolah menjadi bahan teknik seperti genteng, dinding, plafon bahkan dapat 
dikembangkan menjadi material otomotif, sebagiaman penelitian yang dilakukan oleh salah satu perusahaan mobil asal Amareika Serikat. Sabut kelapa tersebut digunakan untuk beberapa bagian interior mobil seperti dashboard [2].

Tujuan yang hendak dicapai dalam penelitian ini yaitu menentukan efek lama perendaman serat sabut kelapa terhadap daya serap serat sabut kelapa pada matriks poliester. Hasil penelitian ini akan menjadi dasar pada perlakuan lanjutan serat sabut kelapa sebagai penguat komposit. Daya serap serat terhadap matriks akan memberi gambaran tentang kemampuan perikatan antara serat dengan matriks. Kemampuan perikatan tersebut akan menentukan sifat mekanik komposit seperti tegangan tarik, lentur, impak, dan tegangan geser. Oleh karena itu, peneltian ini sangat urgen untuk dilaksanakan. Temuan yang ditargetkan dalam kegiatan penelitian ini yaitu menentukan lama perendaman yang tepat (apakah 1, 3, 5, 7, 9, atau 11 jam) pada serat sabut kelapa dengan larutan alkali $20 \%$ yang akan menentukan daya serap serat terhadap matriks poliester.

\section{Tinjauan Pustaka}

Komposit adalah gabungan dua atau lebih material yang berbeda menjadi suatu kesatuan yang menyatu dan memiliki sifat-sifat baru yang lebih baik dari unsur pembentuknya. Komposit terdiri dari dua bagian yaitu serat sebagai penguat dan matriks sebagai pengikat. Beberapa contoh komposit yang sering dijumpai disekita kita yaitu (1) beton bertulang, dan (2) badan perahu layar. Beton bertulan terdiri dari besi sebagai seratnya, dan beton sebagai matriksnya, sedangkan badan perahu layar tersusun dari serat gelas dan matriks poliester [3].

Sebelum memanfaatkan serat alam sebagai penguat komposit, serat yang sering digunakan yaitu serat karbon, serat gelas, keramik. Akan tetapi dengan kelebihan yang dimiliki serat alam menyebabkan serat alam sudah mulai digunakan sebagai salah satu alternatif sebagai penguat komposit [4]. Secara umum dikenal tiga kelompok komposit yaitu komposit serat, komposit laminer, dan komposit partikel. Sedangkan komposit polimer ialah makrokomposit bermatriks polimer. Polimer yang biasa digunakan untuk matriks komposit adalah polimer termoplastik misalnya polietilena, polipropilena, dan termoset misalnya poliester, fenol formaldehida, epoksi [5].

Bahan Lignoselulosa merupakan jenis bahan yang mengandung lignin, selulosa, dan hemiselulosa sebagai unsur utamanya.. Hemiselulosa dan selulosa pada struktur bahan lignoselulosa diselubungi atau terikat oleh lignin (Gambar 1). Struktur lignin sendiri sangat rapat dan kuat sehingga menyulitkan bagi enzim pemecah hemiselulosa dan selulosa untuk bisa masuk ke dalam. Selain lignin, faktor lain yang juga dapat menghambat kerja enzim adalah struktur selulosa itu sendiri. Struktur selulosa terbagi menjadi dua yaitu crystalline region (struktur selulosa lurus dan rapat) dan amorphous region (struktur selulosa lebih renggang). Struktur kristalin selulosa merupakan salah satu yang dapat menghambat kerja enzim.

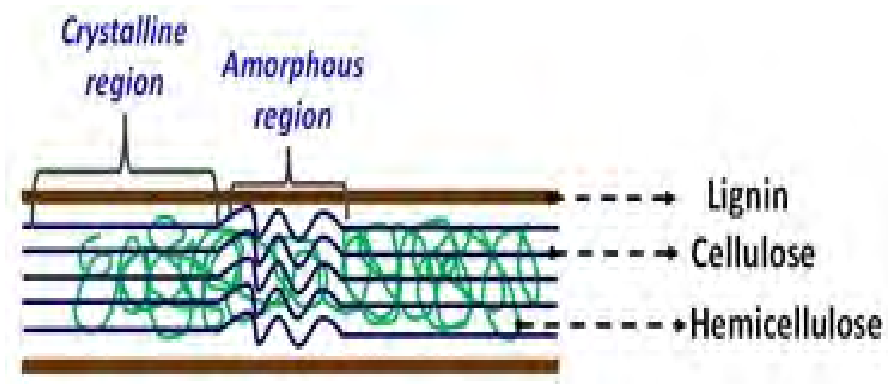

Gambar 1 Hubungan antara lignin, selllulosa, dan Hemisellulosa [6]

Perlakuan secara kimiawi dapat dilakukan dengan dua cara yaitu menggunakan larutan basa atau larutan asam. Diantara kedua tipe pelarut, pelarut yang lebih efektif memecah lignin ialah pelarut basa seperti natrium hidroksida. Akan tetapi, penggunaan senyawa kimia secara berlebihan akan berdampak buruk bagi lingkungan, dapat menghasilkan senyawa toksik yang justru akan menghambat proses hidrolisis polisakarida pada tahap selanjutnya. Oleh karena itu, saat ini para peneliti mulai mengembangkan metode lain yang lebih ramah lingkungan. Perlakuan secara fisis diantaranya ialah penggilingan, iradiasi, pemberian suhu tinggi, dan steam explosion. Perlakuan jenis ini cukup efektif dalam memecah lignin, hanya saja aplikasinya menggunakan energi yang sangat banyak sehingga meningkatkan biaya produksi. Perlakuan secara mikrobiologis merupakan perlakuan yang mulai banyak 
untuk diteliti saat ini. Perlakuan mikrobiologis sebelumnya kurang banyak digunakan karena membutuhkan waktu yang lama dalam mendegradasi lignin secara sempurna. Selain itu, perlakuan mikrobiologis juga bisa menyebabkan terjadinya penurunan kadar selulosa dan hemiselulosa sehingga jumlah selulosa dan hemiselulosa yang bisa dimanfaatkan menjadi berkurang. Meskipun demikian, perlakuan mikrobiologis ini menjadi sangat menarik karena merupakan perlakuan yang paling ramah terhadap lingkungan [5]. Matriks bersifat hydrophobic sedangkan serat bersifat hydrophilic. Kedua sifat tersebut saling bertenangan sehingga serat perlu diberikan perlakuan. Salah satu cara untuk mengurangi sifat hydrophilic serat yaitu perlakuan alkali. Berkurangnya sifat hydrophilic serat akan memberikan ikatan interfacial dengan matriks secara optimal. Sifat mekanis komposit sangat dipengaruhi oleh perikatan antara matriks dan serat [7].

Menurut Khalil [8] karakteristik komposit berpenguat serat alam yang dihasil tergantung pada serat, penyebaran serat, dan interaksi antara serat dengan matriks. Selain itu, sifatnya bergantung kepada ikatan permukaan antara matriks dengan serat, sifat serat, ukuran serat, bentuk serat, jumlah serat dalam matriks, teknik pemrosesan, dan penyebaran serat dalam matriks. Selain perlakuan kimia yang dapat menentukan sifat suatu komposit yang dihasilkan, dipengaruhi juga oleh beberapa kondisi serat seperti bagaimana serat itu diperoleh, ukuran, dan bentuk serat. Ukuran dan bentuk serat sangat diperlukan untuk tujuan yang tertentu seperti pemrosesan dan perekatan dengan matriks.

Unsur utama serat alam ialah sellulosa dan lignin. Jumlah sellulosa dalam serat alam sangat tergantung pada jenis serat dan umur tanaman serat tersebut. Meskipun struktur kimia sellulosa dari berbagai jenis serat alam sama namun derajat polimerisasinya berbeda. Rumus molekul selulosa ialah $\left(\mathrm{C}_{6} \mathrm{H}_{10} \mathrm{O}_{5}\right) \mathrm{n}$ dan $\mathrm{n}$ merupakan derajat polimerisasi, dan bisa berupa angka ribuan. Derajat polimerisasi tersebut akan mempengaruhi panjang rantai suatu rangkaian selulosa. Sifat-sifat mekanik suatu serat sangat tergantung pada derajat polimerisasinya [9]. Serat atau fiber dalam bahan komposit berperan sebagai bagian utama yang menahan beban, sehingga besar kecilnya kekuatan bahan komposit sangat tergantung dari kekuatan serat pengisinya. Semakin kecil diameter serat maka semakin kuat bahan tersebut, karena minimnya cacat pada material [7]. Selain itu, serat juga merupakan unsur yang terpenting, karena seratlah nantinya yang akan menentukan sifat mekanik komposit tersebut seperti kekakuan, keuletan, kekuatan. Fungsi utama serat dalam komposit yaitu : (a) Sebagai pembawa beban, (b) memberikan sifat kekakuan, kekuatan, stabilitas panas dan sifat-sifat lain dalam komposit, (c) memberikan konduktivitas pada komposit.

Sabut kelapa merupakan bagian terluar buah kelapa. Ketebalan sabut kelapa berkisar 5-6 cm yang terdiri atas lapisan terluar (exocarpium) dan lapisan dalam (endocarpium). Endocarpium mengandung serat halus yang bisa digunakan sebagai penguat komposit. Satu butir buah kelapa menghasilkan $0,4 \mathrm{~kg}$ sabut yang mengandung $30 \%$ serat. Identitas morfologi penampang terhadap serat sabut kelapa menunjukkan bahwa serat sabut kelapa memiliki banyak rongga. Bahkan terdapat lubang yang cukup besar berada di tengah-tengah diameternya. Luas lubang ini diperkirakan $\pm 5 \%$ luas lingkaran penampang melintangnya, ukuran diameter rata-ratanya ialah $236 \mu \mathrm{m}[10]$.

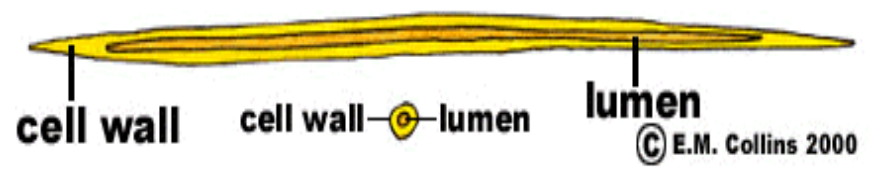

Gambar 2. Bagian-bagian Serat Sebat Kelapa [10]

Perlakuan alkali ini bertujuan untuk melarutkan lapisan yang menyerupai lilin di permukaan serat, seperti lignin, hemiselulosa, dan kotoran lainnya. Dengan hilangnya lapisan lilin ini maka ikatan antara serat dan matriks akan menjadi lebih kuat, sehingga kekuatan tarik komposit menjadi lebih tinggi. Namun demikian, perlakuan alkali yang lebih lama dapat menyebabkan kerusakan pada unsur selulosa. Padahal, selulosa itu sendiri sebagai unsur utama pendukung kekuatan serat. Akibatnya, serat yang dikenai perlakuan alkali terlalu lama mengalami degradasi kekuatan yang signifikan. 
Sebagai akibatnya, komposit yang diperkuat serat rami dengan perlakuan alkali yang lebih lama memiliki kekuatan yang lebih rendah. Regangan bahan komposit berpenguat serat rami juga menunjukkan adanya optimasi perlakuan 5\% alkali serat. Pada komposit yang diperkuat serat rami tanpa perlakuan, kegagalan didominasi oleh lepasnya ikatan antara serat dengan matriks yang diakibatkan oleh tegangan geser di permukaan serat. Kegagalan tersebut didominasi oleh lepasnya ikatan serat dan matriks. Jenis kegagalan ini sering disebut dengan istilah fiber pull out. Pada kondisi kegagalan ini, matriks dan serat sebenarnya masih mampu menahan beban dan meregang yang lebih besar. Namun, berhubung ikatan antara serat dan matriks gagal, maka komposit pun mengalami kegagalan lebih awal. Perlakuan alkali memiliki efek tertinggi pada kekuatan tarik dan modulus tarik, menghasilkan komposit dengan sifat tarik terbaik. Perlakuan alkali tersebut akan (1) meningkatkan kekasaran permukaan serat sehingga akan menghasilkan interlocking yang lebih baik, (2) akan meningkatkan jumlah sellulosa yang terlepas [9].

\section{Metode Penelitian}

Serat sabut kelapa yang digunakan berasal dari sabut kelapa kering yang berwarna coklat tua. Warna tersebut menjadi tanda bahwa sabut kelapa berasal dari pohon kelapa yang sudah tua. Serat sabut kelapa dipisahkan dari sabutnya dengan menggunakan tangan, dengan cara mengurai satu demi satu. "Gabus" yang masih melekat pada serat dibersihkan atau dilepaskan dengan menggunakan tangan.

Peralatan yang digunakan terdiri dari wadah perendaman, gelas ukur $500 \mathrm{~mL}$, timbangan digital, lidi, spoit, dan mikroskop digital dengan pembesaran hingga 500 kali. Sedangkan bahan yang digunakan terdiri dari serat sabut kelapa, larutan natrium hidroksida, aquades, katalis mekpo dan matriks polyester.

Pelaksanaan penelitian terdiri dari beberapa tahapan yaitu perendaman, pengeringan serat, penginjeksian matriks pada permukaan serat, dan pengukuran sudut wetabiliti. Serat sabut kelapa direndam dalam larutan natrium hidroksida $(\mathrm{NaOH} 20 \%)$ selama 1, 3, 5, 7, 9, dan 11 jam. Setelah itu, dibilas dengan aquadeskemudian dikeringkan dalam suhu ruang. Serat sabut kelapa yang telah kering, dipasang atau diikat pada lidi kemudian ditancapkan pada gabus, agar posisi serat dapat meregang. Setelah itu, matriks poliester yang telah dicampur dengan katalis mekpo diinjeksi dengan menggunakan spoit pada permukaan serat sabut kelapa. Hal ini dilakukan pada beberapa lokasi. Setelah kering, maka matriks poliester yang terdapat pada permukaan serat sabut kelapa difoto dan diukur sudut wetabilitinya dengan menggunakan mikroskop digital. Selanjutnya, nilai-nilai yang diperoleh disusun dalam bentuk tabel untuk dianalisa.

\section{Hasil Dan Pembahasan}

Tabel 1 memperlihatkan sudut wetabiliti serat sabut kelapa, baik yang belum direndam maupun setelah direndam. Sudut wetabilitni serat setelah perendaman $(1 \mathrm{H}$ s.d $11 \mathrm{H})$ menurun dibandindingkan dengan serat sebelum perendaman $(0 \mathrm{H})$, sudut wetabiliti terkecil diperoleh pada perendaman 5 jam $(5 \mathrm{H})$ yaitu $15,327^{\circ}$. Sudut kontak antara perikatan matriks dengan permukaan serat yang membentuk sudut kurang dari $90^{\circ}$ berarti mampu basah, sedangkan bila sudut kontaknya lebih dari $90^{\circ}$ berarti tidak mampu basah, semakin kecil sudut kontak wettability semakin baik. Sudut kontak yang baik untuk menghasilkan kemampuan basah optimal ialah sudut kontak tidak lebih dari $30^{\circ}$ [4]. Hal ini menunjukkan bahwa perendaman serat sabut kelapa dalam larutan $\mathrm{NaOH} 20 \%$ memberikan kemampuan basah dibandingkan dengan serat sabut kelapa yang tidak direndam. Lama perendaman yang memberikan sudut wetabiliti terbaik yaitu pada perendaman 5 jam karena memberikan sudut terkecil sebesar $15,327^{\circ}$.

Tabel 1. Hasil Pengukuran Sudut Wetabiliti

\begin{tabular}{|c|c|c|c|c|c|}
\hline \multirow{2}{*}{ No } & \multirow{2}{*}{$\begin{array}{c}\text { Kode } \\
\text { Spesimen }\end{array}$} & \multicolumn{3}{|c|}{ Hasil Pengukuran $\left({ }^{\circ}\right)$} & Rata-Rata \\
\cline { 3 - 5 } & 1 & 2 & 3 & $\left({ }^{\circ}\right)$ \\
\hline 1 & $0 \mathrm{H}$ & 36,064 & 33,537 & 23,259 & 30,953 \\
\hline 2 & $1 \mathrm{H}$ & 21,764 & 28,728 & 20,353 & 23,615 \\
\hline 3 & $3 \mathrm{H}$ & 18,503 & 20,056 & 39,699 & 26,086 \\
\hline 4 & $5 \mathrm{H}$ & 19,099 & 12,56 & 14,323 & 15,327 \\
\hline 5 & $7 \mathrm{H}$ & 17,726 & 26,301 & 16,899 & 20,309 \\
\hline 6 & $9 \mathrm{H}$ & 16,966 & 24,171 & 29,908 & 23,682 \\
\hline 7 & $11 \mathrm{H}$ & 26,711 & 24,734 & 28,346 & 26,597 \\
\hline
\end{tabular}




\section{Kesimpulan}

Sebagaimana hasil pengujian yang telah dilakukan, maka dapat disimpulkan bahwa perendaman serat sabut kelapa dalam larutan $\mathrm{NaOH} 20 \%$ mempengaruhi Sudut wetabiliti serat setelah perendaman menurun dibandindingkan dengan serat sebelum perendaman, sudut wetabiliti terkecil diperoleh pada perendaman 5 jam yaitu $15,327^{\circ}$.

\section{Ucapan Terima Kasih}

Kegiatan penelitian ini terlaksana atas bantuan dari pimpinan Politeknik Negeri Ujung Pandang (PNUP), baik bantuan dana melalui DIPA PNUP, maupun bantuan berupa izin penggunaan segala fasilitas bengkel dan laboratorium yang ada di lingkungan PNUP. Oleh karena itu, kami tak lupa mengucapkan terima kasih yang tak terhingga.

\section{Daftar Pustaka}

[1] Wagenugraha, 2008. Material Komposit Tangguh Berbasis Serat Alam

http://www.wagenugraha.wordpress.com/2008/09/21/materikomposit-tangguh-berbasis-serat-alam/

[2] Mahaputra, Sandy Adam. Sabut Kelapa, Bahan Dasar Mobil Masa Depan. www.vivanews.com/news/read/253664-sabutkelapa--bahan-dasar-mobil-masa-depan. 08 Oktober 2011

[3] Djaprie, Sriati. 1992. Ilmu dan Teknologi Bahan. Penerbit Erlangga : Jakarta.

[4] Marsyahyo, E., 2009. Perlakuan Permukaan Serat Rami (Boehmeria nivea) dan Kompatibilitas Serat-Matrik pada Komposit matrik Polimer : Disertasi, Yogyakarta : Universitas Gajah Mada.

[5] Daulay, L.R., 2009. Adhesi Penguat Serbuk Pulp Tandan Kosong Sawit Teresterifikasi Dengan Matriks Komposit Polietilena : Disertasi. Medan : Universitas Sumatera Utara.

[6] https://cropstechnology.wordpress.com/category/biopolymer/

[7] Hartanto, L., 2009. Study Perlakuan Alkali dan Fraksi Volume Serat terhadap Kekuatan Bending, Tarik, dan Impak Komposit Berpenguat Serat Rami

[8] Khalil, H.P.S.A., Alwani, M.S., Omar, A.K.M. 2006. Chemical Composition, Anatomy, Lignin Distribution, and Cell Wall Structure of Malaysian Plant Waste Fibers. J.Bioresources 1 (2): $220-232$.

[9] Mohanty, A.K., Misra,M., Drzal,L.T., 2005. Natural Fibers, Biopolymers, And,Biocomposites. New York : CRC Press Taylor \& Francis Group

[10] Waifilate, Afa Austin, 2008. Mechanical Property Evaluation of Coconut Fibre. Sweden : Department of Mechanical Engineering Blekinge Institute of Technology.

[11] Bermatrik Polyester BQTN 157 : Skripsi. Surakarta : Universitas Muhammadiyah Surakarta. 